Research, part of a Special Feature on Landscape Scenarios and Multifunctionality - Making Land Use Assessment Operational

\title{
Evaluating Today's Landscape Multifunctionality and Providing an Alternative Future: A Normative Scenario Approach
}

\author{
$\underline{\text { Rainer Waldhardt }}^{1}$, Martin Bach ${ }^{2}$, René Borresch ${ }^{3}$, Lutz Breuer ${ }^{2}$, Tim Diekötter ${ }^{4}$, Hans-Georg Frede ${ }^{2}$, \\ Stefan Gäth ${ }^{5}$, Oliver Ginzler ${ }^{1}$, Thomas Gottschalk ${ }^{4}$, Stefan Julich ${ }^{2}$, Matthias Krumpholz ${ }^{6}$, \\ Friedrich Kuhlmann ${ }^{6}$, Annette Otte ${ }^{1}$, Birgit Reger ${ }^{1}$, Wolfgang Reiher ${ }^{2}$, Kim Schmitz, ${ }^{3}$, \\ P. Michael Schmitz ${ }^{3}$, Patrick Sheridan ${ }^{6}$, Dietmar Simmering ${ }^{9}$, Cornelia Weist ${ }^{7}$, Volkmar Wolters ${ }^{4}$, and \\ Dorit Zörner ${ }^{5}$
}

\begin{abstract}
Intensive agriculture has had multiple negative effects on the environment across large areas of Europe, including a decrease in the degree to which these landscapes serve multiple functions. A quantitative evaluation of the deficits in landscape multifunctionality is difficult, however, for a given landscape as long as "multifunctional reference landscapes" are lacking. We present an interdisciplinary normative scenario approach to overcome this obstacle. Given the example of the lower Wetter-catchment in the Wetterau region (Hesse, Germany), we compare the existing landscape with an expert-generated multifunctional landscape scenario that may also serve as an alternative future. This approach may inspire policy makers and land users by providing a methodology for the design of alternative multifunctional futures in five steps: (1) documentation of today's landscape structure and land use at the scale of uniformly managed land units; (2) detection of functional deficits of today's landscape considering environmental (soil contamination, groundwater production, water quality, biodiversity), economic (land rent), and societal (landscape perception by its population) attributes; (3) compilation of a catalogue of alternative land uses (including linear landscape elements) suitable to minimize the detected functional deficits; (4) rule-based modification of today's land-use pattern into a normative scenario; and (5) comparison of today's landscape and the normative scenario by applying the model network ITE2 $\mathrm{M}$. Results highlight a strongly unbalanced allocation of private and public goods in today's landscape with severe deficits in environmental and societal landscape features, but a significantly higher land rent. The designed multifunctional scenario, instead, may be preferred by the local population, and their willingness to pay for multifunctionality could potentially compensate calculated opportunity costs. Hence, the generated landscape scenario may be regarded as an alternative, multifunctional future.
\end{abstract}

Key Words: agriculture; ecosystem services; Germany; modeling; sustainability

\section{INTRODUCTION}

For thousands of years, farmers have not only produced food and fiber (private goods), but have also affected multiple ecosystem functions, such as biodiversity, water, and soil quality, or provided cultural identity (public goods). However, most agricultural landscapes have not met all the complex and sometimes contradicting requirements and expectations of society (Helming and Wiggering 2003), neither in the past nor today. This holds especially true for highly productive regions that are dominated by either intensive dairy production or cash crop farming. There, high value-added production goes hand in hand with well-known ecosystem changes, such as biodiversity loss (Benton et al. 2003, Donald et al. 2006, Billeter et al. 2008), that result from eutrophication, pesticide

\footnotetext{
${ }^{1}$ Landscape Ecology and Landscape Planning, Justus-Liebig-University Giessen, ${ }^{2}$ Resources Management, Justus-Liebig-University Giessen, ${ }^{3}$ Agricultural and Development Policy, Justus-Liebig-University Giessen, ${ }^{4}$ Animal Ecology, Justus-Liebig-University Giessen, ${ }^{5}$ Waste Management and Environmental Research, Justus-Liebig-University Giessen, ${ }^{6}$ Agribusiness Management, Justus-Liebig-University Giessen, ${ }^{7}$ Biometry and Population Genetics, JustusLiebig-University Giessen
} 
use, low habitat diversity and quality, and altered landscape structure. Moreover, such landscapes barely provide recreational, cultural, and esthetic experiences (Dramstad et al. 2001, Gobster et al. 2007), which are particularly needed in highly urbanized societies.

The concept of multifunctionality in agriculture, which was drafted at the Rio Earth Summit of 1992 (UNCED 1992), is a valuable conceptual framework, within which landscape ecology can address the imbalances in the allocation of private and public goods in agricultural landscapes (cf. Mander et al. 2007). Multifunctionality may be described in terms of optimal land allocation: "agricultural land is optimally allocated if it fulfills the mixture of functions demanded by society" (Jongeneel et al. 2008). Aside from the concept of multifunctionality, the concepts of sustainable development and ecosystem services have also been used to help define relationships between society and nature. Sustainable development refers to the vulnerability of ecosystems and the need for conserving resources to ensure long-term delivery of ecosystem functions. According to the World Commission on Environment and Development, sustainable development "meets the needs of the present without compromising the ability of future generations to meet their own needs" (WCED 1987). Sustainability is generally understood to include the dimensions of ecological, economic, and societal perspectives. Ecosystem services are defined as the benefits people obtain from ecosystems (MA 2003) and directly address ecological, economic, and societal functions.

Based on the premise that the global demand for multifunctionality, sustainability, and ecosystem services will substantially increase in the future (Alcamo et al. 2005, Huber et al. 2007), and that agriculture has dramatically increased its ecological footprint (Butler et al. 2007), alternative pathways toward multifunctionality and sustainable development, such as a sound implementation of agrienvironment schemes at the landscape scale (Herzog 2005), are urgently needed. In the European Union, multifunctionality of agriculture has become the key concept or a new paradigm for agriculture and rural development (Tait 2001, Van Huylenbroeck and Durand 2004). With a wide array of conceptualizations, agricultural multifunctionality has also attracted attention in other parts of the world (e.g., Anderson 2000, Bills and Gross 2005, Cocklin et al. 2006, and cf. Wilson 2007). Thus, policy needs to cope with the challenges of trade-offs between the three dimensions of landscape functions (and services) and even between different measures within one of these dimensions, if the vision of multifunctionality is to be translated into reality at the landscape scale. In general, this challenge requires inter- and multidisciplinary work, and during the last decade, many researchers have undertaken efforts in developing scientifically sound approaches (e.g., Wiggering et al. 2006, Gimona and van der Horst 2007, Groot et al. 2007, Parra-López et al. 2008) to promote the implementation of multifunctional land use at the landscape scale.

Such approaches need to consider two main research components: (1) the evaluation of the status quo of landscape multifunctionality (ex-post evaluation) or of scenarios of future land use (exante evaluation) that might become reality under certain societal and political developments and decisions (e.g., Sharma et al. 2006, Sheate et al. 2008), and (2) the design of alternative futures "that portray futures that should be" (Nassauer and Corry 2004). In both research components, three main challenges must be addressed: the need for interand transdisciplinary approaches and tools that cover the three dimensions of landscape functions (e.g., Mattison and Norris 2005, Groot et al. 2007, Rossing et al. 2007), consideration of scales (e.g., Dunford and Freemark 2004, Rodríguez et al. 2006), and the need to develop spatially transferable approaches.

Against this background, our interdisciplinary research group developed an integrated, five-step, indicator-based approach to evaluate the multifunctionality of intensively used agricultural landscapes and applied this approach to a highly productive agricultural landscape in Germany. As a reference landscape for the evaluation of today's land use, we designed a normative multifunctional landscape scenario (MS). Based on a set of ecological and economic indicators derived from spatially explicit, high-resolution landscape models, we compare today's land use, represented in a base scenario (BS), with the MS. The selected ecological indicators relate to soil quality, water, and biodiversity and thus cover the main environmental landscape functions that may be impaired in intensively used agricultural landscapes. The selected economic indicators provide a deepened insight into the regional value added and transfer payments. Moreover, we evaluated the people's perception of 
both today's and the designed landscape and estimated the willingness of the local population to pay for multifunctional agriculture.

This paper presents the methodological steps of the approach, gives an example of the application of this approach, and discusses the interdisciplinary methodology, its limitations, and usefulness for decision makers and farmers.

\section{STUDY REGION}

The lower Wetter-catchment $\left(166 \mathrm{~km}^{2}\right)$, located in the Wetterau region in the German Federal State of Hesse, was selected as the study region. In the larger area of the Wetterau at altitudes between 120 and $250 \mathrm{~m}$ above sea level, fertile and well-drained luvisols are predominant (outside of the alluvial plains of small rivers). Mean annual temperature is $9^{\circ} \mathrm{C}$, duration of the growing season (number of days with an average daily temperature $>5^{\circ} \mathrm{C}$ ) is 240 days, and average annual precipitation is about $600 \mathrm{~mm}$.

The Wetterau has been populated since Paleolithic times, and cultivation of arable land, which is still typical of the scenery today (about $40 \%$ of the entire area and about $70 \%$ of the agricultural land), dates back five thousand years. In the recent past, crops were cultivated on small fields with mean field size below 1 ha, as delineated from air photos dating back to 1950 . The landscape scenery included a pronounced network of farm tracks and traditional apple orchards in close proximity to the settlements. Today, large portions of the former apple orchards are either lost due to residential development or under cultivation. Moreover, field sizes increased significantly as a result of land consolidation (present day mean field size is about 2.0 ha, which is comparatively large for Hesse). Wheat, barley, rapeseed, maize, and sugar beet are the most important crops in short crop rotations. In general, today's agricultural land use intensity is high with respect to fertilization and pesticide application.

Today, the agricultural land of the Wetterau is considered an area that does not provide much space for biodiversity. Population sizes and occurrence frequencies of formerly common wildlife species, such as the common hamster (Cricetus cricetus), have dramatically decreased. Moreover, abiotic resources have been negatively impacted by agricultural practices, including high nitrate concentrations in rivers, heavy metal enrichment in arable soils from the use of sewage sludge, and soil water erosion on arable land. Finally, due to the predominance of arable fields and short crop rotations, today's landscape scenery is monotonous and less attractive for recreation and tourism in large parts of the region. Thus, the study region is characterized by a suboptimal allocation of private and public goods and may not fulfill the requirements of landscape multifunctionality.

\section{METHODOLOGY: FIVE-STEPAPPROACH}

To evaluate today's landscape multifunctionality, we developed a five-step approach. We compare a generalized view of today's landscape (BS) with an expert-generated multifunctional landscape scenario (MS) that aims to meet the requirements of multifunctionality. This expert-generated alternative future is meant to be considered by policy makers and farmers as one possible solution to today's environmental and societal deficits in land use. In general, our approach is applicable not only to the region under study, but to all intensively used agricultural landscapes, provided that the required input data are available.

\section{Step 1: Documentation of today's landscape structure and land use at the scale of uniformly managed land units (designing of the BS)}

We used digital information at the scale of uniformly managed land units (patch scale) on landcover classes such as arable land or grassland derived from air photo interpretation (conducted by EFTAS Remote Sensing Transfer of Technology $\mathrm{GmbH}$, Münster, Germany), soil types (digital soil map 1:50,000), and topography (digital elevation model; resolution $20 \mathrm{~m}$ ), provided by the Hessian State Agency for Environment and Geology. Further, we defined site-specific agricultural production systems (based on field expertise and agricultural statistics) to document today's landscape structure and land use. Data were stored in Microsoft Access databases and linked to ArcGIS 9.1 to allow for visualization. Overlay analysis of different thematic layers resulted in a generalized view of today's landscape (BS). 


\section{Step 2: Detection of functional deficits of today's landscape}

Designing a normative future requires expertise of the landscape under study and, moreover, of agricultural production systems and their potential effects on landscape functions. Members of all participating research groups of the Agricultural Faculty of Giessen University have been familiar with the study region for several years. Even prior to our study, environmental problems (e.g., low biodiversity at the patch scale) resulting from agriculture were obvious in the Wetterau region. However, detailed data needed for a qualified detection of functional deficits were initially unavailable. As these were also essential for indicator-based modeling, we conducted empirical research (e.g., water chemical analyses and vegetation surveys) and additionally evaluated regional agricultural statistics to broaden and deepen our expertise on today's functional deficits related to landscape structure and agricultural land use.

\section{Step 3: Compilation of a catalogue of alternative land uses (including linear landscape elements)}

Informed by the data compiled in Steps 1 and 2, and cognizant of the obligations affecting agricultural land use in Germany and the EU (e.g., Water Framework Directive, Nitrate Directive, Soil Protection Act, Nature Conservation Act, AgriEnvironment Schemes), each participating group evaluated from its disciplinary view the potential of certain measures or land use systems (e.g., measures contemplated in agri-environment schemes [HIAP: Hessian Integrated Agri-Environment Scheme; HMULV 2007], reduced soil tillage, or organic production systems) to enhance or impair the respective environmental landscape functions (chemical soil quality, hydrology, floristic diversity, faunistic diversity). Given a multitude of potentially suitable agricultural practices (cf., e.g., Herzog 2005, Marshall etal.2006), this step resulted in a list of disciplinary ideas that were compiled in a catalogue of alternative land uses.

\section{Step 4: Rule-based modification of today's land use pattern into a normative scenario}

Based on this catalogue, we determined rules for the spatially explicit incorporation of these alternative land uses in the MS. Through extensive interdisciplinary discussions, we found balanced compromises among conflicting goals related to the landscape functions under consideration. We did not aim to design an entirely new landscape, but to find a science-based pragmatic approach toward a balance of productive and nonproductive functions at the landscape scale. With the help of standard ArcGIS techniques, the rules were used to modify the BS and hence to create a landscape model of the MS.

\section{Step 5: Comparison of today's landscape and the normative scenario}

To evaluate the degree of landscape multifunctionality of the BS against the MS, we applied the indicatorbased model network ITE $2 \mathrm{M}$, which was originally developed as an integrated tool for the development and evaluation of economically and ecologically sustainable options for regional land use (Frede and Bach 2002, Waldhardt 2007, Schaldach and Priess 2008). Previous applications of the ITE2 M models concentrated on the evaluation of land use scenarios that might become reality for certain developments in the European Common Agricultural Policy (CAP). Details on the underlying theories and concepts, methodologies and limitations, and disciplinary and interdisciplinary results have been published elsewhere (see Table 1). They will thus not be presented here in detail, but are briefly outlined below. In this study, the ITE2 $\mathrm{M}$ modeling focused on a set of indicators (Table 1) that were selected based on the results gained in Step 2.

For both scenarios, the GIS-based ITE2 $\mathrm{M}$ models ATOMIS, SWAT, ProF, GEPARD, and ProLand calculated indicator values (I) related to spatial units ranging from $100 \mathrm{~m}^{2}$ up to 25 ha (Table 1). These reference units reflect the different spatial scales that, in previous studies, were found to be appropriate for each indicator. To evaluate the BS at the scale of the reference units, we calculated the differences of each indicator value $(\Delta \mathrm{I})$ between the $\mathrm{BS}$ and the MS: 
Table 1. The model network ITE2M with its indicators, spatial reference units, and model output considered in this study. All models, with the exception of SWAT (Arnold et al. 1998), were developed in the research groups contributing to this study.

\begin{tabular}{|c|c|c|c|c|c|}
\hline Acronym & Name & $\begin{array}{l}\text { Selected } \\
\text { publications }\end{array}$ & $\begin{array}{l}\text { Indicators considered } \\
\text { in this study }\end{array}$ & $\begin{array}{l}\text { Spatial } \\
\text { reference unit }\end{array}$ & Model output \\
\hline ATOMIS & $\begin{array}{l}\text { Assessment Tool } \\
\text { for Metals in Soils }\end{array}$ & $\begin{array}{l}\text { Breuer et al. 2007, } \\
\text { Reiher } 2008\end{array}$ & $\begin{array}{l}\mathrm{Cu}, \mathrm{Zn} \text {, and } \mathrm{Cd} \text { input } \\
\text { loads and topsoil } \\
\text { concentrations }\end{array}$ & $20 \times 20 \mathrm{~m}$ & Means per ha \\
\hline SWAT & $\begin{array}{l}\text { Soil and Water } \\
\text { Assessment Tool }\end{array}$ & $\begin{array}{l}\text { Fohrer et al. 2005, } \\
\text { Breuer et al. } 2007\end{array}$ & $\begin{array}{l}\text { Nitrate-N loads, } \\
\text { discharge, } \\
\text { evapotranspiration }\end{array}$ & $100 \times 100 \mathrm{~m}$ & $\begin{array}{l}\text { Means per ha and } \\
\text { year }\end{array}$ \\
\hline ProF & $\begin{array}{l}\text { Prognosis of } \\
\text { Floristics }\end{array}$ & $\begin{array}{l}\text { Waldhardt et al. } \\
\text { 2004, Sheridan } \\
\text { and Waldhardt } \\
2006\end{array}$ & $\begin{array}{l}\text { Plant species richness, } \\
\text { richness in insect- } \\
\text { pollinated species, and } \\
\text { low-nutrient } \\
\text { indicators }\end{array}$ & $500 \times 500 \mathrm{~m}$ & Means per 25 ha \\
\hline GEPARD & $\begin{array}{l}\text { Geographically } \\
\text { Explicit Prediction } \\
\text { of Animal } \\
\text { Richness } \\
\text { Distributions }\end{array}$ & $\begin{array}{l}\text { Gottschalk et al. } \\
\text { 2007, 2009, } 2010\end{array}$ & $\begin{array}{l}\text { Breeding populations } \\
\text { of nine indicator bird } \\
\text { species }\end{array}$ & $10 \times 10 \mathrm{~m}$ & Means per $100 \mathrm{~m}^{2}$ \\
\hline ProLand & $\begin{array}{l}\text { Prognosis of Land } \\
\text { Use }\end{array}$ & $\begin{array}{l}\text { Möller 1998, } \\
\text { Möller et al. 2002, } \\
\text { Weinmann 2002, } \\
\text { Weinmann et al. } \\
\text { 2006, Sheridan } \\
\text { and Waldhardt } \\
\text { 2006, Sheridan et } \\
\text { al. 2007 }\end{array}$ & $\begin{array}{l}\text { Land rent, transfer } \\
\text { payments, } \\
\text { recommendation on } \\
\text { N-fertilization }\end{array}$ & Land parcel & $\begin{array}{l}\text { Means per ha and } \\
\text { year }\end{array}$ \\
\hline CHOICE & $\begin{array}{l}\text { Choice Valuation } \\
\text { of Non- } \\
\text { Commodities }\end{array}$ & $\begin{array}{l}\text { Schmitz et al. } \\
\text { 2003, Borresch et } \\
\text { al. 2005, Schmitz } \\
2008\end{array}$ & $\begin{array}{l}\text { Willingness to pay for } \\
\text { landscape scenery }\end{array}$ & Landscape & $\begin{array}{l}\text { Willingness to pay } \\
\text { per household and } \\
\text { year }\end{array}$ \\
\hline
\end{tabular}

$$
\Delta \mathrm{I}=\mathrm{I}_{\mathrm{BS}}-\mathrm{I}_{\mathrm{MS}}
$$

To allow for an integrated ecological-economic evaluation of today's multifunctionality at the scale of the entire study region, we aggregated the spatially explicit indicator values by calculating mean indicator values $(\bar{T})$ for both BS and MS, and the BS was evaluated against the MS as follows:

$$
\overline{\mathrm{I}}_{\mathrm{BS}} / \bar{\top}_{\mathrm{MS}} \times 100 \%
$$

Our comparison of the BS and the MS also included the people's perception of landscape scenery. In this regard, we applied the CHOICE modeling and assessment framework by means of a comprehensive cost-benefit analysis and the calculation of the willingness of the local people to pay for the landscape scenery under both landscape scenarios. The CHOICE modeling also estimated the consumer surplus per household resulting from a change from $\mathrm{BS}$ to $\mathrm{MS}$, and we related this consumer surplus to the respective opportunity costs calculated in ProLand. 
In the following paragraphs, we give some outline information on the ITE2M models and their application in this study.

\section{ATOMIS:}

The model ATOMIS calculates the potential accumulation of heavy metals for each agriculturally managed patch depending on deposition and fertilizers (organic and conventional pig slurry and cattle manure, sewage sludge, mineral NPK-fertilizer [applied to conventional managed sites], and rock phosphate [applied to organic fields]). Calculations are based on site-specific pedotransfer functions and thus reflect soil sorption characteristics. In this study, the amount of applied farmyard manure was determined by the P-demand (in the model network, this information is provided by ProLand), whereas its composition was in accordance with today's regional livestock density. Moreover, in this study, modeling of heavy metal accumulation was calculated over a period of 100 years.

\section{SWAT:}

Modeling of water quality and quantity in the widely established SWAT model refers to nine subcatchments of the study region, delineated with the help of a digital elevation model (cf. Step 1). Subcatchments are further subdivided into hydrological response units (HRU) considering data on production systems (e.g., amount of $\mathrm{N}$ fertilization; in the model network, this information is provided by ProLand) and soil quality. On the level of the HRU, the model calculates the hydrological as well as the nutrient balance on a daily time step. In this study, for both scenarios, the simulation period was 1990-2002, and the first five years were used as a warm-up phase to reach equilibrium in the model's water and nutrient storage.

\section{ProF:}

Modeling of plant species richness in ProF is based on the simplifying assumption of a binomial distribution of plant species within the patches of predefined habitat types. ProF uses the probability of plant species occurrence in habitat types, and the respective number of habitat patches, to estimate the species richness of complex habitat patterns of a given discretionary size (in this study, $25 \mathrm{ha}$ ). The definition of habitat types for this study was restricted to agricultural land. For the $\mathrm{BS}$, we considered the habitat types (1) grassland (on dry, moderate, and wet soils), (2) fruit orchards (on either acidic or base-rich soils), and (3) arable land (classified as winter wheat, winter and summer barley, rape seed, corn, potato, sugar beet fields). For the MS, reflecting the incorporation of alternative land uses (cf. Table 2), we additionally defined (4) extensively managed grassland types on moderate and wet soils, (5) extensively managed perennial field margins, (6) organic fields, (7) wild flower fields, and (8) extensively managed (annual) field margins for each crop. The occurrence probabilities in habitat groups 1-5 were derived from their respective frequency in field data (30 species lists per habitat type; field studies conducted in 2006 and 2007 as part of Step 2). For habitats only stated in the MF (groups 6-8), we used the same species lists but employed expert knowledge to adjust the expected higher probabilities of occurrence in these habitat types.

\section{GEPARD:}

In this study, the breeding populations of nine farmland indicator bird species (SISD, Stickroth et al. 2004) were modeled. For seven species, we used resource-selection functions based on species' distributions and land use information (maps of the BS and the MS). Abundances for Skylark (Alauda arvensis) and Yellowhammer (Emberiza citronella) were required in 300 five-minute Point Counts using Distance Sampling (Buckland et al. 2001) (field studies in 2006 and 2007 as part of Step 2). Presences of Little Owl (Athene noctua), Lapwing (Vanellus vanellus), and Corn Bunting (Miliaria calandra) (HGON 2005, unpublished data) as well as Red Kite (Milvus milvus) and Red-backed Shrike (Lanius collurio) (HGON 1998, unpublished data) were based on 400 available nest records. Twenty land use and topographical variables entered the generalized linear models (GLM) while establishing resource-selection functions using GEPARD. Estimated occurrence probabilities per pixel for rare species were translated into abundances by multiplying them with literature-based breeding densities (Bauer et al. 2005). Because Black-tailed Godwit (Limosa limosa) and Whinchat (Saxicola rubetra) were absent in today's landscape, existing knowledge on their habitat requirements was used to predict their breeding-population sizes in the MS rather than resource-selection functions. 
Table 2. Aggregated list of alternative land uses (including linear landscape elements), rules for their incorporation in the MS, and main goals.

\begin{tabular}{lcc}
\hline \hline Alternative land uses & Rules & Main goals \\
\hline
\end{tabular}

\section{Land parcels}

Field aggregation Aggregation of fields with $>4 \%$ slope to units with $>100 \mathrm{~m}$ width to facilitate cultivation in slope-parallel direction

Organic farming

Conversion from conventional to organic farming; reduced tillage; about $15 \%$ of today's arable land

Flowering fields

Grassland, extensive I

Grassland, extensive II

Apple orchards with HIAP ${ }^{\dagger}$; random selection from fields $<2$ ha; about $3 \%$ of today's arable land

Extensive grassland use in accordance with HIAP (e.g., without fertilization, mown once or twice a year); random selection of $75 \%$ of the grassland along the river Wetter and all arable land on either wet (gley soils) or dry soils (rankers)

Land use as before, but mowing not before July; random selection of $25 \%$ of the grassland along the river Wetter
Conversion of arable land and grassland next to relicts of formerly extensive apple orchards; directed selection of about $0.5 \%$ of the total area
Reduce variable costs; reduce soil erosion

Reduce fertilizer input; provide habitats for a rich arable vegetation and fauna; reduce the risk of $\mathrm{N}$-input in water

Reduce fertilizer input; provide habitats for fauna; protect the soils

Provide nesting habitat for endangered grassland bird species; reduce fertilizer input; provide habitats for rich grassland vegetation and fauna

Improve landscape esthethics; provide habitats for fauna

Provide habitats for arable vegetation, other plants, and fauna

Provide habitat for perennial grassland species and fauna

Modest improvement of the existing hedge network as habitats for plants and wildlife

${ }^{\dagger}$ HIAP, Hessian Integrated Agri-environment Scheme; HMULV 2007. 


\section{ProLand:}

In this analysis, ProLand calculated land rents for given exogenous spatial distributions of the various land use types in the study region. Land rent is defined as the factor income of land, i.e., for any single agricultural land use:

Land rent $=$ biomass yield $\times$ product price + transfer payments - factor costs |abor, capital

ProLand first estimates site-specific yields of all crops under investigation using linear-limitational yield functions. It then calculates revenues and costs for each individual field. Consequently, different input and output levels are explicitly modeled, e.g., biomass production, fertilizer input, or labor requirements. The model assumes full divisibility and unlimited supply regardless of demand at given prices of inputs and outputs. It accounts for all factor costs and thus allows comparison of agricultural land use alternatives. Land rents of crop rotations are equal to the averages of the land rents of the constituting crops weighted with their respective share in the rotation. Five conventional crop rotations with three crops each and two types of conventional grassland based on the current land use (information gained in Step 2) in the study area were defined in the BS. The changes on arable land and grassland introduced in the MS required three conventional crop rotations with four crops each, six organic rotations with five or six crops, four types of grassland, and two agri-environment schemes. Calculating land rent and transfer payment differences between the MS and BS resulted in estimates of the measures' opportunity costs. Due to the fact that $\mathrm{N}$-fertilization strongly affects environmental goods, such as biodiversity or water quality, we additionally calculated the amount of $\mathrm{N}$ fertilization recommended under both scenarios.

\section{CHOICE:}

The modeling and assessment framework CHOICE is based on the well-established methods of choice experiments (e.g., Hanley et al. 2001) and costbenefit analysis (e.g., Just et al. 2004). In choice experiments, a series of alternatives for selected indicators are presented, and respondents are asked to choose their most preferred alternative. Choice experiments are particularly suited to investigate situations where changes are multidimensional and trade-offs between them are of particular interest.
However, as is the case with all preference techniques, the obtained welfare estimates are sensitive to the study design, e.g., the choice of attributes, and it is important to account for cognitive difficulties associated with multiple, complex choices (Hanley et al. 2001). Therefore, the chosen indicators for this study were kept as simple as possible. We asked the local population for their willingness to pay for the following environmental goods: water quality (nitrate-N loads), plant species richness, breeding populations of birds, and landscape scenery, given five parameter values (scenarios) for each indicator. Here, we focus on the willingness to pay for alternative landscape sceneries. The five scenarios of landscape scenery (MS, BS, intensive scenario with increased field sizes, high commodity price scenario with predominance of cereals, and grassland scenario with predominance of grassland) were visualized with the help of maps and photographs. In 2007, 420 structured, personal interviews were conducted with local people between 18 and 75 years old. In the cost-benefit analysis, we calculated the consumer surplus per household resulting from a change from BS to MS and related this consumer surplus to the respective opportunity costs. Positive (Negative) results of cost-benefit analyses indicate positive (negative) impact on social welfare.

\section{RESULTS}

Step 1 resulted in a high-resolution map of today's landscape (BS, Fig. 1a, b) and related statistics (Table 3). Each arable land and grassland patch distinguished in the map was allocated to either one of the five conventional crop rotations or to one of the two types of conventional grassland management schemes to allow for site-specific modeling of the ecological and economic indicator values under the BS.

Results gained in Steps 2-4 are presented as an aggregated overview of the alternative land uses incorporated in the MS (Tables 2 and 3). In the MS, compared to the BS, the diversity of land use classes (Table 3) is considerably higher, and thus landscape structure is much more diverse (Fig. 1c). In the two scenarios, $21 \%$ of the entire acreage is in different land use, which is mainly due to the conversion of conventional arable land into alternative land uses in the MS. Here, each arable land or grassland patch 
Fig. 1. Pattern of land cover/land use classes in the study area. (a) Land cover classes of the BS. (b, c) Land use classes of the BS and the MS in an exemplary subregion.

a)

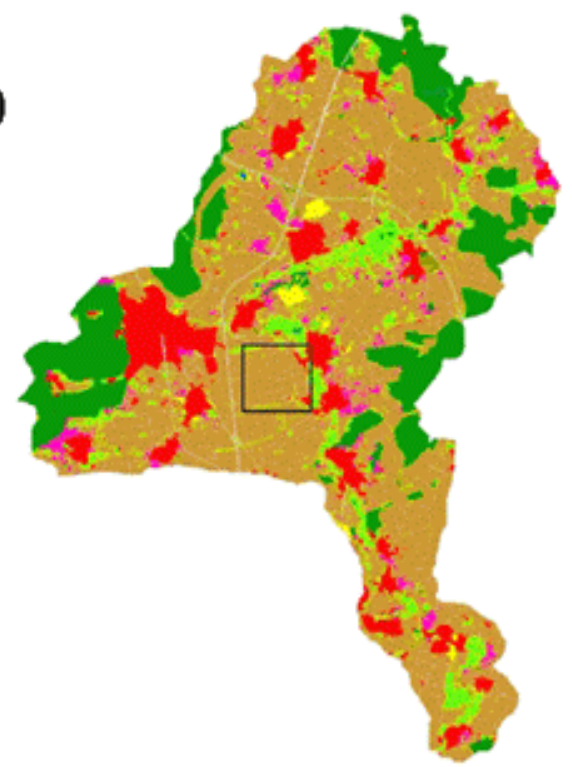

b)

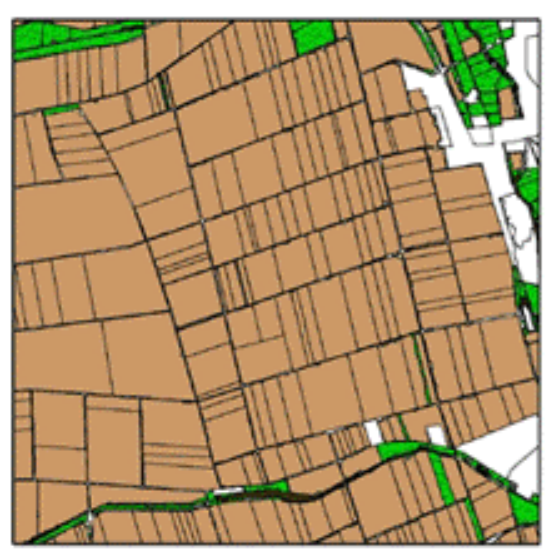

Arable land

Flowering fields

Extensively managed field margins

Rest Perennial field margins
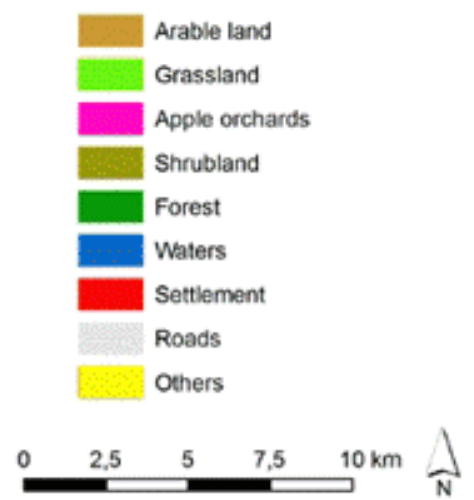

c)

MS

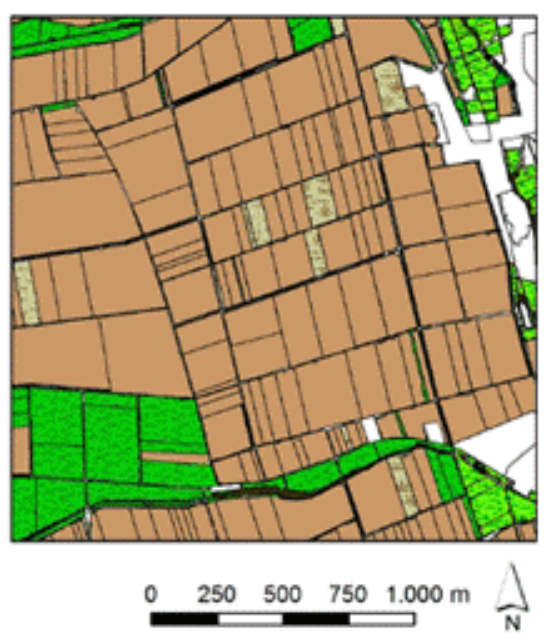

Gras strips

Grassland, intensive

Alley

Others 
Table 3. Proportions of land uses in the BS and the MS.

\begin{tabular}{|c|c|c|}
\hline & \multicolumn{2}{|c|}{ Percent $(\%)$ of Total Area } \\
\hline & $\mathrm{BS}^{\dagger}$ & $\mathrm{MS}^{\ddagger}$ \\
\hline Arable land, conventional & 52.1 & 34.6 \\
\hline \multicolumn{3}{|l|}{ Arable land, conventional, converted to: } \\
\hline Arable land, organic & & 8.7 \\
\hline Flowering fields & & 1.4 \\
\hline Extensively managed field margins & & 0.3 \\
\hline Perennial field margins & & 0.3 \\
\hline Hedges & & $<0.1$ \\
\hline Grassland, intensive & & 3.7 \\
\hline Grassland, extensive I & & 2.0 \\
\hline Grassland, extensive II & & 0.5 \\
\hline Apple orchards & & 0.6 \\
\hline Grassland, intensive & 8.2 & 3.9 \\
\hline \multicolumn{3}{|l|}{ Grassland, intensive, converted to: } \\
\hline Grassland, extensive I & & 3.0 \\
\hline Grassland, extensive II & & 1.0 \\
\hline Hedges & & $<0.1$ \\
\hline Apple orchards & & 0.4 \\
\hline Apple orchards & 3.4 & 3.4 \\
\hline Grass strips & 1.7 & 1.7 \\
\hline Alley & 0.9 & 0.9 \\
\hline Others & 33.6 & 33.6 \\
\hline Total area: 16,628 ha & & \\
\hline
\end{tabular}

${ }^{\dagger} \mathrm{BS}$, generalized view of today's landscape.

${ }^{\dagger} \mathrm{MS}$, expert-generated multifunctional landscape scenario. 
was allocated to one of the conventional crop rotations, organic rotations, grassland management, or agri-environment schemes defined in ProLand modeling. These patch data and the information on linear landscape elements implemented in the MS allowed for site-specific modeling of the ecological and economic indicator values.

At the scale of the indicator-specific spatial reference units (Fig. 2, Table 4), the disciplinary evaluation of today's land use (BS) against the MS highlights functional deficits of the BS, mainly with respect to biodiversity (differences in plant species richness and Yellowhammer territories between the BS and the MS are often below zero, indicating lower biodiversity in the BS) and water quality (differences between nitrate- $\mathrm{N}$ loads between the BS and the MS are often above zero, indicating higher nitrate-N loads in the BS). In contrast, from the economist's view, higher land rent in the BS may result in a negative evaluation of the MS. However, in some reference units, the expected land rent is higher under the MS, indicating that today's land use is not economically optimized in all reference units. In general, the spatial pattern of areas with functional deficits in the BS differs according to the respective landscape function or service: The lower numbers of Yellowhammer territories are concentrated in the northeastern part of the study region, whereas high $\mathrm{Cu}$-loads are widely spread throughout the region.

At the scale of the entire study region, Fig. 3 highlights the imbalance in the allocation of private and public goods under the BS and thus in today's landscape. On the one hand, our results clearly reveal environmental deficits under the BS for most of the indicators. For example, $\mathrm{N}$ - and Cd-loads are higher in the BS compared to the MS, and the numbers of Red-backed Shrike breeding populations and low-nutrient indicators in the vegetation have lower values in the BS. With respect to the indicator bird species, similar results were found for Lapwing and Little Owl. Breeding populations for the Lapwing and the Little Owl in the BS were lower than in the MS (71\% and $77 \%$, respectively). Moreover, Black-tailed Godwit and Whinchat, absent in today's landscape, are expected to occur under the MS ( 2 and 39 breeding populations are predicted). On the other hand, Skylark and Corn Bunting are expected to reach larger breeding populations under the BS (133\% and $125 \%)$ than under the MS. The BS is therefore positively evaluated for these two bird species. This positive evaluation of the BS also holds true for the economic indicators land rent (in Fig. 3, higher indicator value in the BS) and transfer payments (lower indicator value in the BS). Average opportunity costs of the MS amount to $161 € \mathrm{ha}^{-1} \mathrm{a}^{-1}$ (decrease of land rent $=110 € \mathrm{ha}^{-1} \mathrm{a}^{-1}$; increase of transfer payments = $51 € \mathrm{ha}^{-1} \mathrm{a}^{-1}$ ). Finally, recommended Nfertilization is higher in the BS than in the MS. This result may provide the first insight into underlying ecological processes that have resulted in today's environmental deficits (higher N-loads and lower number of nutrient indicators in the BS).

Given the results at both spatial scales, the MS is evaluated as an alternative future with more desirable environmental outcomes than the current baseline. Results of the CHOICE modeling clearly show that the multifunctional scenario would also be preferred by the local population: The willingness to pay for multifunctionality (calculated implicit price $=88 €$ ) is much higher than it is for the other scenarios of landscape scenery that were considered in the interviews (grassland scenario $=$ $48 € ; \mathrm{BS}=0 €$; intensive scenario $=-13 € ;$ high price scenario $=-16 €$ ). Moreover, conversion of the present landscape scenery (BS) to the landscape scenery (MS) may result in a consumer surplus of $228 €$ per household and year. Given the number of about 40,100 households in the study region and the opportunity costs of $161 € \mathrm{ha}^{-1} \mathrm{a}^{-1}$, the estimated net benefit of the MS amounts to $389 € \mathrm{ha}^{-1} \mathrm{a}^{-1}$. Thus, this analysis indicates that implementation of the MS would lead to greater benefits for society.

\section{DISCUSSION}

Although the necessity of inter- and transdisciplinary studies to evaluate landscape multifunctionality has been frequently emphasized (Naveh 2001, Tress and Tress 2001, Frede et al. 2002, Helming and Wiggering 2003), integrative studies considering ecological, economic, and social landscape functions are rather scarce (but see Nassauer and Corry 2004, Santelmann et al. 2004, Wiggering et al. 2006). Fry (2001) and Tress and Tress (2001) have pointed out manifold difficulties involved in inter- and transdisciplinary landscape research, which are partly rooted in different academic traditions and languages but also in the complexity of landscape as a research object. Our approach, in which scientists generate a normative scenario by 
Fig. 2. Standardized differences in indicator values as calculated for indicator-specific reference units. Standardization against min. $\left(\Delta^{-}\right)$, mean $(\Delta 0)$, and max. $(\Delta+)$ indicator values. Red color: functional deficits. Non-agricultural land (mainly forests and settlements) was excluded from data analyses.
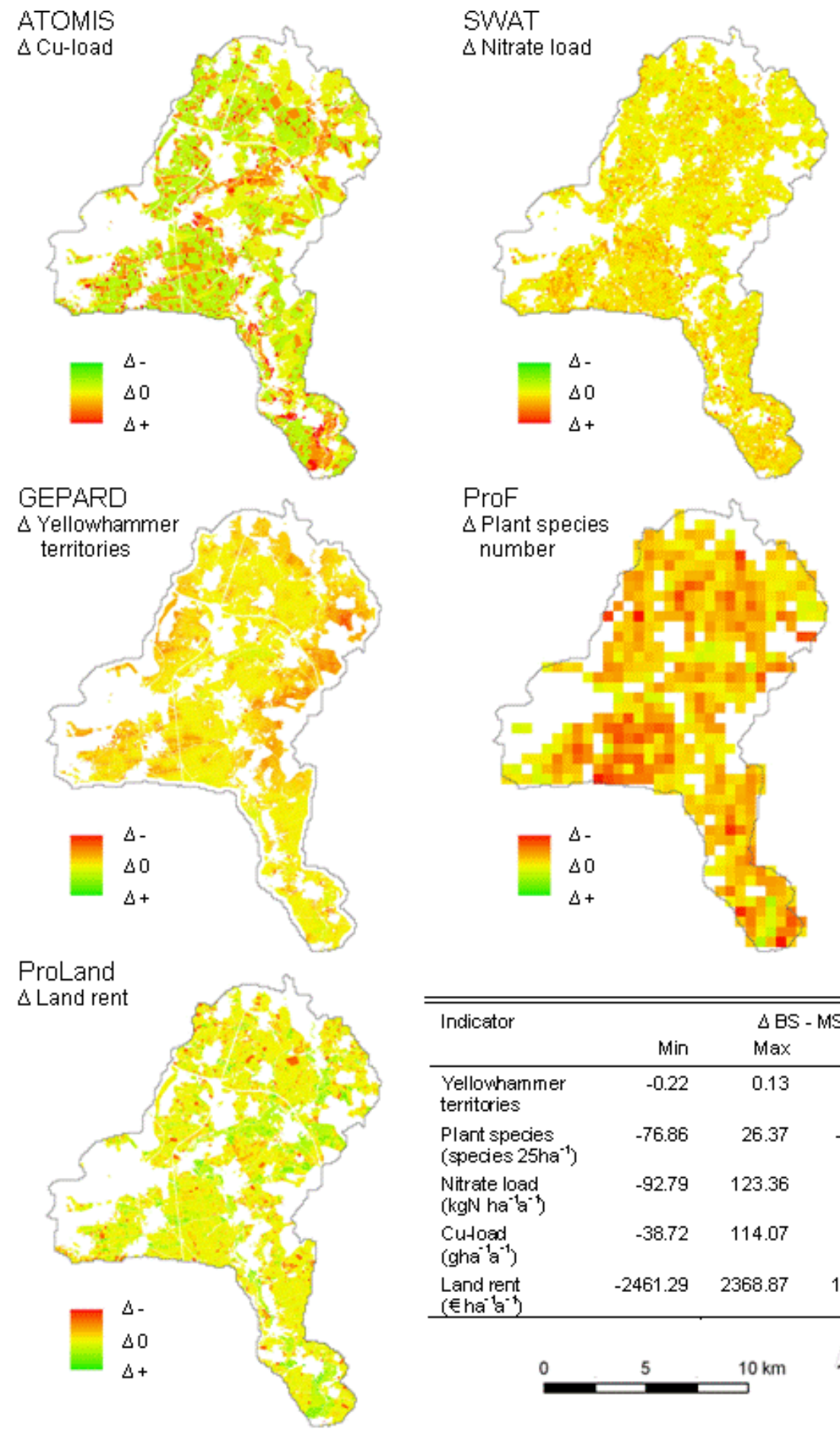

\begin{tabular}{|c|c|c|c|c|}
\hline \multirow[t]{2}{*}{ Indicator } & \multicolumn{4}{|c|}{$\triangle \mathrm{BS}-\mathrm{MS}$} \\
\hline & Min & $\operatorname{Max}$ & Mean & Std dev. \\
\hline $\begin{array}{l}\text { Yellowhammer } \\
\text { territories }\end{array}$ & -0.22 & 0.13 & -0.03 & 0.03 \\
\hline $\begin{array}{l}\text { Plant species } \\
\text { (species } 25 \mathrm{ha}^{-1} \text { ) }\end{array}$ & -76.86 & 26.37 & -19.08 & 18.16 \\
\hline $\begin{array}{l}\text { Nitrate load } \\
\left(\mathrm{kgNN} \mathrm{ha}^{-1} \mathrm{a}^{-1}\right)\end{array}$ & -92.79 & 123.36 & 7.77 & 16.17 \\
\hline $\begin{array}{l}\text { Cutood } \\
\left(g^{-1} a^{-1}\right)\end{array}$ & -38.72 & 114.07 & -0.95 & 41.31 \\
\hline $\begin{array}{l}\text { Land rent } \\
\left.\text { (Ena } a^{-1} a^{-1}\right)\end{array}$ & -2461.29 & 2368.87 & 110.30 & 542.86 \\
\hline
\end{tabular}


Table 4. Indicator values in the BS and MS at the scale of spatial reference units. (See Table 1 for spatial reference units.)

\begin{tabular}{|c|c|c|c|c|c|c|c|c|}
\hline \multirow[b]{2}{*}{ Indicator } & \multicolumn{4}{|c|}{$\mathrm{BS}$} & \multicolumn{4}{|c|}{ MS } \\
\hline & Min. & Max. & Mean & Std. dev. & Min. & Max. & Mean & Std. dev. \\
\hline Yellowhammer territories & 0.00 & 0.33 & 0.05 & 0.06 & 0.00 & 0.34 & 0.07 & 0.07 \\
\hline Plant species numbers & 52.54 & 219.39 & 142.17 & 29.93 & 58.68 & 222.50 & 161.25 & 26.23 \\
\hline $\mathrm{N}-\operatorname{load}\left(\mathrm{kg} \mathrm{N} \mathrm{ha}^{-1} \mathrm{a}^{-1}\right)$ & 0.21 & 132.50 & 32.13 & 21.51 & 0.05 & 118.00 & 24.40 & 18.80 \\
\hline Cu-load $\left(\mathrm{g} \mathrm{ha}^{-1} \mathrm{a}^{-1}\right)$ & 38.40 & 146.92 & 122.48 & 28.80 & 32.85 & 183.80 & 123.18 & 53.40 \\
\hline Land rent $\left(€ \mathrm{ha}^{-1} \mathrm{a}^{-1}\right)$ & -768.79 & 1895.46 & 707.16 & 623.96 & -986.12 & 2950.81 & 503.02 & 750.46 \\
\hline
\end{tabular}

'BS, generalized view of today's landscape.

${ }^{\ddagger} \mathrm{MS}$, expert-generated multifunctional landscape scenario.

drawing from regional knowledge, and subsequently, the scenario is evaluated by both scientists and lay people, may partly bridge the gap between interdisciplinary and transdisciplinary research. We did not involve nonscientists in the production but in the integrated evaluation of knowledge gained in an interdisciplinary project, and the results suggest that we produced knowledge that is not only scientifically sound but also socially acceptable. In that, the developed interdisciplinary approach possesses attributes of transdisciplinarity (cf. Gibbons and Nowotny 2001, Maasen et al. 2006).

Due to the complexity of agricultural landscapes and landscapes in general, i.e., the multitude of relationships between land use and ecological, economic, and societal landscape features, scientific research on landscape multifunctionality often concentrates on only a very limited number of landscape functions and thus evaluates only sections of the human-environment system. Moreover, future-oriented evaluation of landscape multifunctionality, similar to many other fields of landscape research, highly depends on indicator-based landscape modeling (Wiggering et al. 2006). The choice of the considered functions, indicators, and models may be scientifically justified by specific landscape settings, but also depends inevitably on pragmatic decisions reflecting regional scientific expertise or funding limitations. As a consequence, a wide range of concepts and approaches (cf. Zander et al. 2006, Renting et al. 2009) was published in previous studies related to this research field: Wiggering et al. (2006) define an indicator of social utility; Gimona and van der Horst (2007) focus on hotspots of multiple landscape functions; Groot et al. (2007) developed an "interactive multi-goal agricultural landscape generation and evaluation system"; and Parra-López et al. (2008) explicitly integrate public demands and alternatives available by the supply part of the market. Although we acknowledge that other landscapes may require different approaches, our concern here is not to identify which landscapes may require different approaches or to assess which of these concepts and approaches are most likely to result in appropriate knowledge. Rather, our purpose is to illustrate the need for and utility of spatially explicit normative landscape scenarios in the research on and evaluation of landscape multifunctionality.

Studies on landscape multifunctionality focus on either ex-post evaluation of today's landscapes or ex-ante evaluation of potential futures. Special attention has been given to political developments and decisions and their potential effects on landscape functions (e.g., Möller and Weinmann 2001, Santelmann et al. 2004, Boody et al. 2005, Sheridan and Waldhardt 2006, Gottschalk et al. 2007, Mittenzwei et al. 2007, Reger et al. 2009, cf. 
Fig. 3. Integrated evaluation of today's landscape at the scale of the entire study region. Shown are indicator values of the BS in percent of the MS indicator values. Red (green) dots: Negative (Positive) evaluation of the BS in comparison to the MS. The estimated MS indicator values are given in brackets as mean/reference unit or total values. ET, evapotranspiration.

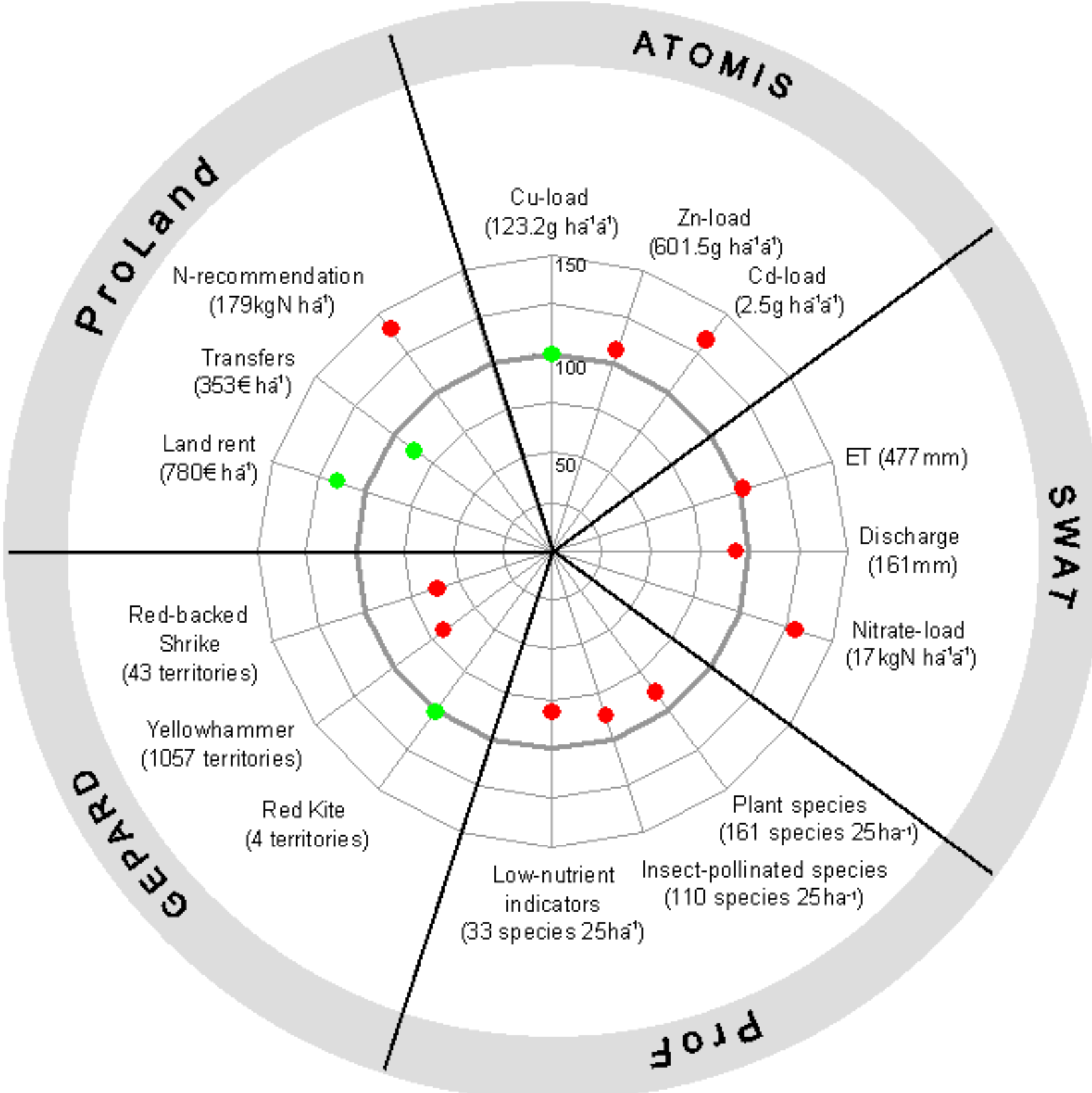


Otte et al. 2007). In these studies, potential futures were either compared among each other or related to the status quo. In an analogous way, this also holds true for studies on the sustainable development of landscapes (Rasul and Thapa 2003, Parra-López et al. 2009, cf. Büchs 2003) and on landscape services (e.g., Alcamo et al. 2005, Tscharntke et al. 2005, Müller and Burkhard 2007). In contrast to the present paper, these studies did not use a normative reference landscape to evaluate the degree of multifunctionality, sustainability, or services that could be achieved in a given landscape. In general, only few spatially explicit research efforts (e.g., Meyer and Grabaum 2008) have been undertaken to develop multifunctional futures at the landscape scale. Our normative scenario approach may encourage other research teams to explore the potential landscape multifunctionality and sustainability using normative future scenarios rather than current baseline landscapes as the benchmark for evaluation of multifunctionality and sustainability.

Our approach to design one multifunctional reference landscape, albeit founded on interdisciplinary scientific knowledge, will likely generate different results depending on the participating disciplines, researchers, and also on the information gained in the first three steps of the process. Although our alternative future was expected to positively affect landscape multifunctionality from our scientific perspective, the rules we determined and the landscape we designed should not be seen as the only solution for landscape multifunctionality. Considering the multiplicity of landscapes and landscape functions, any given landscape should be viewed as being positioned in a broader multidimensional space of landscape functions. Within this multidimensional space, multifunctional landscapes are located within the domains limited by the lower threshold values of (indicators of) landscape functions. Hence, there are potentially a large number of possible solutions to landscape multifunctionality. In that, the results of the fourth and fifth steps of our approach presented here may be considered as a first pass of an iterative procedure to develop and evaluate additional alternative futures within the domain of landscape multifunctionality.

Further, a designed multifunctional future represents only a snapshot in time due to changing input and output prices and changing societal demands (Alcamo et al. 2005, Huber et al. 2007, Jongeneel et al. 2008). Recent developments of rising input costs and declining output prices may result in lower overall estimates of the land rent. Moreover, politically induced market distortions, such as bioenergy support, may introduce new biomass crops, which are economically more profitable than current cropping systems. Such interventions will possibly lead to an increase of opportunity costs.

Our results at the scale of indicator-specific spatial reference units show that the designed alternative future cannot simultaneously decrease environmental deficits in all spatial reference units. In some parts of the landscape under study, environmental deficits are even expected to increase, if today's landscape is altered according to the normative scenario. Moreover, biotic indicators, even if they belong to the same indicator species group (e.g., bird species considered in this study; cf. also Gottschalk et al. 2010), may be affected in opposite directions. In general, these effects reflect both specific landscape settings and modeling rules (e.g., species' habitat preferences) applied in the ITE $^{2} \mathrm{M}$ models. Consequently, disciplinary cause-effect analyses within the ITE ${ }^{2} \mathrm{M}$ model network could improve the understanding of the relationships between land use and the degree of landscape functionality and should allow for an iterative development of additional alternative futures. In such an extended approach, many more indicators (e.g., different species groups) and additional landscape functions (cf. De Groot 2006) than presented in this study may also be integrated. As part of an ongoing research project at Giessen University, a landscape model on land use-dependent $\mathrm{CO}_{2}$ emission has been developed and integrated within the ITE² $\mathrm{M}$ network.

Despite the limitations discussed above, our evaluation of landscape multifunctionality in the Wetterau region highlights a strongly unbalanced allocation of private and public goods in today's landscape: Severe deficits in environmental and societal landscape features go hand in hand with high land rent. Thus, a modification of today's landscape is imperative to meet the requirements of landscape multifunctionality in the study region. In this context, the normative scenario designed to increase landscape multifunctionality may be viewed as one alternative future toward a balance of productive and nonproductive functions in the study region. We are aware of the limited potential of landscape modeling approaches to contribute to multifunctional agriculture (cf. Groot et al. 2009). As outlined in Methodology, we also acknowledge potential limitations in using willingness to pay data in the economic evaluation of our scenarios. 
Nevertheless, we hope that our results may stimulate decision makers and farmers to adapt and expand the implementation of agri-environment schemes, which will eventually lead to more multifunctional landscapes. According to our results, today's land use is not economically optimized in all reference units. Our results should encourage farmers to consider conversion to alternative production systems used in our scenario, such as organic farming.

Our results suggest that spatially explicit, informed decision making will be required to achieve agricultural landscapes in which land use meets the needs of the ecosystem and society at the patch as well as the landscape scale. But even if this challenge is met, the alleged dilemma of trade-offs among landscape functions remains unsolved. Conflicting and contradicting states of landscape functions are inherent characteristics of the ecosystem "landscape" and are of fundamental importance for self-organization and positive feedbacks in disturbed landscapes (cf. Perry 2002). However, the ultimate goal of sustainable land use management is to find balanced compromises between environmental, societal, and economic landscape functions. The approach presented here may be of use in finding these compromises.

Responses to this article can be read online at: http://www.ecologyandsociety.org/vol15/iss3/art30/ responses/

\section{Acknowledgments:}

This study was carried out as part of the Deutsche Forschungsgemeinschaft (DFG) Collaborative Research Centre (SFB) 299 (http://www.sfb299.de). We thank the DFG for financial assistance. Further, we thank Wilfried Hausmann, Ralf Eichelmann, Günther Herbert, Udo Seum, Werner Peter, Rainer Holler, and Karl-Heinz Clever for providing bird nest records; Carsten Haub and his co-workers at EFTAS for satisfying our needs in air photo interpretation; two anonymous reviewers for valuable comments on earlier drafts of the paper; and Mary Santelmann for an inspiring workshop.

\section{LITERATURE CITED}

Alcamo, J., D. van Vuuren, C. Ringler, W. Cramer, T. Masui, J. Alder, and K. Schulze. 2005. Changes in nature's balance sheet: model-based estimates of future worldwide ecosystem services. Ecology and Society 10(2): 19. [online] URL: http: //www.ecologyandsociety.org/vol10/iss2/art19/.

Anderson, K. 2000. Agriculture's "multifunctionality" and the WTO. The Australian Journal of Agricultural and Resource Economics 44:475-494.

Arnold, J. G., R. Srinivasan, R. S. Muttiah, and J. R. Williams. 1998. Large area hydrologic modeling and assessment. Part I: model development. Journal of the American Water Resources Association 34:73-89.

Bauer, H.-G., E. Bezzel, and W. Fiedler. 2005. Das kompendium der vögel Mitteleuropas. Aula, Wiebelsheim, Germany.

Benton, T. G., J. A. Vickery, and J. D. Wilson. 2003. Farmland biodiversity: is habitat heterogeneity the key? Trends in Ecology and Evolution 18: $182-188$.

Billeter, R., L. Liira, D. Bailey, R. Bugter, P. Arens, I. Augenstein, S. Aviron, J. Baudry, R. Bukacek, F. Burel, M. Cerny, G. De Blust, R. De Cock, T. Diekötter, H. Dietz, J. Dirksen, C. Dormann, W. Durka, M. Frenzel, R. Hamersky, F. Hendrickx, F. Herzog, S. Klotz, B. Koolstra, A. Lausch, D. Le Coeur, J. P. Maelfait, P. Opdam, M. Roubalova, A. Schermann, N. Schermann, T. Schmidt, O. Schweiger, M. J. M. Smulders, M. Speelmans, P. Simova, J. Verboom, W. van Wingerden, M. Zobel, and P. J. Edwards. 2008. Indicators for biodiversity in agricultural landscapes: a pan-European study. Journal of Applied Ecology 45:141-150.

Bills, N., and D. Gross. 2005. Sustaining multifunctional agricultural landscapes: comparing stakeholder perspectives in New York (US) and England (UK). Land Use Policy 22:313-321.

Boody, G., B. Vondracek, D. A. Andow, M. Krinke, J. Westra, J. Zimmerman, and P. Welle. 2005. Multifunctional agriculture in the United States. BioScience 55:27-38. 
Borresch, R., B. Weinmann, F. Kuhlmann, and P. M. Schmitz. 2005. Interdisciplinary modelling and assessment of multifunctionality. Pages 330-350 in F. Arfini, editor. Modelling agricultural policies: state of the art and new challenges. Monte Università Parma Editore, Parma, Italy.

Breuer, L., W. Reiher, T. Pohlert, J. A. Huisman, B. Weinmann, K. B. Vaché, M. Bach, and H.-G. Frede. 2007. Integrated assessment of potential impacts on water and soil related ecosystem services due to the European Common Agricultural Policy. Pages 90-95 in A. Schumann and M. Pahlow, editors. Reducing the vulnerability of societies to water related risks at the basin scale. IAHS Press, Wallingford, Oxfordshire, UK.

Büchs, W. 2003. Biotic indicators for biodiversity and sustainable agriculture - introduction and background. Agriculture, Ecosystems \& Environment 98:1-16.

Buckland, S. T., D. R. Anderson, K. P. Burnham, J. L. Laake, D. L. Borchers, and L. Thomas. 2001. Introduction to distance sampling estimating abundance of biological populations. Oxford University Press, Oxford, UK.

Butler, S. J., J. A. Vickery, and K. Norris. 2007. Farmland biodiversity and the footprint of agriculture. Science 315:381-384.

Cocklin, C., J. Dibden, and N. Mautner. 2006. From market to multifunctionality? Land stewardship in Australia. The Geographical Journal 172:197-205

De Groot, R. 2006. Function-analysis and valuation as a tool to assess land use conflicts in planning for sustainable, multi-functional landscapes. Landscape and Urban Planning 75:175-186.

Donald, P. F., F. J. Sanderson, I. J. Burfield, and F. P. J. van Bommel. 2006. Further evidence of continent-wide impacts of agricultural intensification on European farmland birds, 1990-2000. Agriculture, Ecosystems \& Environment 116:189-196.

Dramstad, W. E., G. Fry, W. J. Fjellstad, B. Skar, C. Helliksen, M.-L. B. Sollund, M. S. Tveit, A. K. Geelmuyden, and E. Framstad. 2001. Integrating landscape-based values - Norwegian monitoring of agricultural landscapes. Landscape and Urban Planning 57:257-268.

Dunford, W., and K. Freemark. 2004. Matrix matters: effects of surrounding land uses on forest birds near Ottawa, Canada. Landscape Ecology 20:497-511.

Ellenberg, H., H. E. Weber, R. Düll, V. Wirth, W. Werner, and D. Paulißen. 1992. Zeigerwerte von pflanzen in Mitteleuropa. Scripta Geobotanica 18: $1-258$.

Fohrer, N., S. Haverkamp, and H.-G. Frede. 2005. Assessment of long-term effects of land use patterns on hydrologic landscape functions sustainable land use concepts for low mountain range areas. Hydrological Processes 193:659-672.

Frede, H.-G., and M. Bach. 2002. Multifunctionality of land use as part of the SFB 299. Berichte über Landwirtschaft 80:325-326.

Frede, H.-G., M. Bach, N. Fohrer, D. Möller, and N. Steiner. 2002. Multifunktionalität der landschaft - methoden und modelle. Petermanns Geographische Mitteilungen 146:58-63.

Fry, G. L. A. 2001. Multifunctional landscapes towards transdisciplinary research. Landscape and Urban Planning 57:159-168.

Gibbons, M., and H. Nowotny. 2001. The potential of transdisciplinarity. Pages 67-80 in J. T. Klein, W. Grossenbacher-Mansuy, and R. Häberli, editors. Transdisciplinarity: joint problem solving among science, technology, and society. An effective way for managing complexity. Birkhäuser, Basel, Switzerland.

Gimona, A., and D. van der Horst. 2007. Mapping hotspots of multiple landscape functions: a case study on farmland afforestation in Scotland. Landscape Ecology 22:1255-1264.

Gobster, P., J. Nassauer, T. Daniel, and G. Fry. 2007. The shared landscape: what does aesthetics have to do with ecology? Landscape Ecology 22:959-972.

Gottschalk, T. K., R. Dittrich , T. Diekötter, P. Sheridan, V. Wolters, and K. Ekschmitt. 2010. 
Modelling land-use sustainability using farmland birds as indicators. Ecological Indicators 10:15-23.

Gottschalk, T. K., T. Diekötter, K. Ekschmitt, B. Weinmann, F. Kuhlmann, T. Purtauf, J. Dauber, and V. Wolters. 2007. Impact of agricultural subsidies on biodiversity at the landscape level. Landscape Ecology 22:643-656.

Gottschalk, T. K., M. Weiste, M. Bertling, T. Reiners, K. Ekschmitt, and V. Wolters. 2009. GEPARD Version 2.0. [online] URL: www.sfb299. de/GEPARD.

Groot, J. C. J., W. A. H. Rossing, A. Jellema, D. J. Stobbelaar, H. Renting, and M. K. Van Ittersum. 2007. Exploring multi-scale trade-offs between nature conservation, agricultural profits and landscape quality - a methodology to support discussions on land-use perspectives. Agriculture, Ecosystems \& Environment 120:58-69.

Groot, J. C. J., W. A. H. Rossing, M. Tichit, N. Turpin, A. Jellema, J. Baudry, P. H. Verburg, L. Doyen, and G. W. J. van de Ven. 2009. On the contribution of modelling to multifunctional agriculture: learning from comparisons. Journal of Environmental Management 90, Supplement 2:147-160.

Hanley N., S. Mourato, and R. E. Wright. 2001. Choice modelling approaches: a superior alternative for environmental valuation? Journal of Economic Surveys 15:435-462.

Helming, K., and H. Wiggering. 2003. Sustainable development of multifunctional landscapes. Springer, Berlin, Heidelberg, Germany.

Herzog, F. 2005. Agri-environment schemes as landscape experiments. Agriculture, Ecosystems \& Environment 108:175-177.

Hessisches Ministerium für Umwelt, ländlichen Raum und Verbraucherschutz (HMULV). 2007. Beihilferichtlinien für die nachhaltige Bewirtschaftung landwirtschaftlicher und naturschutzfachlich wertvoller Flächen in Hessen. Wiesbaden, Germany.

Huber R., T. Haller, M. Weber, and B. Lehmann. 2007. Future societal demand for multifunctionality. Agrarforschung 14:406-411.
Jongeneel, R. A., N. B. P. Polman, and L. H. G. Slangen. 2008. Why are Dutch farmers going multifunctional? Land Use Policy 25:81-94.

Just, R. E., D. L. Hueth, and A. Schmitz. 2004. The welfare economics of public policy-a practical approach to project and policy evaluation. Edward Elgar, Cheltenham, UK, Northampton, Massachusetts, USA.

Millennium Ecosystem Assessment (MA). 2003. Ecosystems and their services. Chapter 2 in Ecosystems and human well-being: a frameworkfor assessment. Island Press, Washington, D.C., USA.

Maasen, S., M. Lengwiler, and M. Guggenheim. 2006. Practices of transdisciplinary research: close (r) encounters of science and society. Science and Public Policy 23:394-398.

Mander, Ü., H. Wiggering, and K. Helming., editors. 2007. Multifunctional land use. Meeting future demands for landscape goods and services. Springer, Berlin, Germany.

Marshall, E.J. P., T. M. West, and D. Kleijn. 2006. Impacts of agri-environment field margin prescription on the flora and fauna of arable farmland in different landscapes. Agriculture, Ecosystems \& Environment 113:36-44.

Mattison, E. H. A., and K. Norris. 2005. Bridging the gaps between agricultural policy, land-use and biodiversity. Trends in Ecology and Evolution 20:610-616.

Meyer, B. C., and R. Grabaum. 2008. MULBO: Model framework for multicriteria landscape assessment and optimisation. A support system for spatial land use decisions. Landscape Research 33:155-179.

Mittenzwei, K., W. Fjellstad, W. Dramstad, O. Flaten, A. K. Gjertsen, M. Loureiro, and S. S. Prestegard. 2007. Opportunities and limitations in assessing the multifunctionality of agriculture within the CAPRI model. Ecological Indicators 7:827-838.

Möller, D. 1998. ProLand: prognose regionaler landnutzungsverteilungen. Schriftenreihe der

Forschungsgesellschaft für Agrarpolitik und Agrarsoziologie 312:113-131. 
Möller, D., N. Fohrer, and N. Steiner. 2002. Quantifizierung regionaler multifunktionalität land- und forstwirtschaftlicher nutzungssysteme. Berichte über Landwirtschaft 80:393-418.

Möller, D., and B. Weinmann. 2001. Multifunktionalität von landschaften: Räumlich differenzierte landnutzungsprognosen als informationsgrundlage zur abschätzung von umweltwirkungen. Berichte der Gesellschaft für Informatik in der Land-, Forstund Ernährungswirtschaft 14:93-96.

Müller, F., and B. Burkhard. 2007. An ecosystem based framework to link landscape structures, functions and services. Pages 37-63 in Ü. Mander, $\mathrm{H}$. Wiggering, and $\mathrm{K}$. Helming, editors. Multifunctional land use. Meeting future demands for landscape goods and services. Springer, Berlin, Germany.

Nassauer, J. I., and R. C. Corry. 2004. Using normative scenarios in landscape ecology. Landscape Ecology 19:343-356.

Naveh, Z. 2001. Ten major premises for a holistic conception of multifunctional landscapes. Landscape and Urban Planning 57:269-284.

Otte, A., D. Simmering, and V. Wolters. 2007. Biodiversity at the landscape level: recent concepts and perspectives for multifunctional land use. Landscape Ecology 22:639-642.

Parra-López, C., J. C. J. Groot, C. CarmonaTorres, and W. A. H. Rossing. 2008. Integrating public demands into model-based design for multifunctional agriculture: an application to intensive Dutch dairy landscapes. Ecological Economics 67:538-551.

Parra-López, C., J. C. J. Groot, C. CarmonaTorres, and W. A. H. Rossing. 2009. An integrated approach for ex-ante evaluation of public policies for sustainable agriculture at landscape level. Land Use Policy 26:1020-1030.

Perry, G. L. W. 2002. Landscapes, space and equilibrium: shifting viewpoints. Progress in Physical Geography 26:339-359.

Rasul, G., and G. B. Thapa. 2003. Sustainability analysis of ecological and conventional agricultural systems in Bangladesh. World Development 31:1721-1741.
Reger, B., P. Sheridan, D. Simmering, A. Otte, and R. Waldhardt. 2009. Potential effects of direct transfer payments on farmland habitat diversity in a marginal European landscape. Environmental Management 43:1026-1038.

Reiher W. 2008. Entwicklung eines regionalisierten modells zur projektion des landnutzungsabhängigen schwermetallstatus von oberböden. Boden und Landschaft $\mathbf{5 2}$.

Renting, H., W. A. H. Rossing, J. C. J. Groot, J. D. Van der Ploeg, C. Laurent, D. Perraud, D. J. Stobbelaar, and M. K. Van Ittersum. 2009. Exploring multifunctional agriculture. A review of conceptual approaches and prospects for an integrative transitional framework. Journal of Environmental Management 90, Supplement 2:112-123.

Rodríguez, J. P., T. D. Beard, Jr., E. M. Bennett, G. S. Cumming, S. Cork, J. Agard, A. P. Dobson, and G. D. Peterson. 2006. Trade-offs across space, time, and ecosystem services. Ecology and Society 11(1): 28. [online] URL: http://www.ecologyandso ciety.org/vol11/iss1/art28/.

Rossing, W. A. H., P. Zander, D. Josien, J. C. J. Groot, B. C. Meyer, and A. Knierim. 2007. Integrative modelling approaches for analysis of impact of multifunctional agriculture: a review for France, Germany and The Netherlands. Agriculture, Ecosystems and Environment 120:41-57.

Santelmann, M. V., D. White, K. Freemark, J. I. Nassauer, J. M. Eilers, K. B. Vache, B. J. Danielson, R. C. Corry, M. E. Clark, S. Polasky, R. M. Cruse, J. Sifneos, H. Rustigian, C. Coiner, J. Wu, and D. Debinski. 2004. Assessing alternative futures for agriculture in Iowa, USA. Landscape Ecology 19:357-374.

Schaldach, R., and J. A. Priess. 2008. Integrated models of the land system: a review of modelling approaches on the regional to global scale. Living Reviews in Landscape Research 2:1.

Schmitz, K. 2008. Die bewertung von multifunktionalität der landschaft mit diskreten choice experimenten. Peter Lang, Frankfurt am Main, Germany. 
Schmitz, K., P. M. Schmitz, and T. C. Wronka. 2003. Integrated ecological and economical valuation of land use systems. Pages 131-152 in M. Kißling, K. Schmitz, P. M. Schmitz, and T.C. Wronka, editors. Pricing environmental services of agriculture. Wissenschaftsverlag Vauk Kiel KG, Kiel, Germany.

Sharma, T., J. Carmichael, and B. Klinkenberg. 2006. Integrated modeling for exploring sustainable agriculture futures. Futures 38:93-113.

Sheate, W. R., M. R. do Partidário, H. Byron, O. Bina, and S. Dagg. 2008. Sustainability assessment of future scenarios: methodology and application to mountain areas of Europe. Environmental Management 41:282-299.

Sheridan, P., O. Schroers, and J. Rommelfanger. 2004. GIS-based modelling of land-use systems. Pages 375-389 in E. Koomen, J. Stillwell, A. Bakema, and H. J. Scholten, editors. Modelling land-use change. Progress and applications. Springer, Heidelberg, Germany.

Sheridan, P., and R. Waldhardt. 2006. Spatially explicit approaches in integrated land use and phytodiversity modelling at multiple scales. Alterra Report 1338:68-72.

Stickroth, H., H. Schlumprecht, and R. Achtziger. 2004. Zielwerte für den "nachhaltigkeitsindikator für die artenvielfalt" - messlatte für eine nachhaltige entwicklung in Deutschland aus sicht des natur- und vogelschutzes. Berichte zum Vogelschutz 41:78-98.

Tait, J. 2001. Science, governance and multifunctionality of European agriculture. Outlook on Agriculture 30:91-95.

Tress, B., and G. Tress. 2001. Capitalising on multiplicity: a transdisciplinary systems approach to landscape research. Landscape and Urban Planning 57:143-157.

Tscharntke, T., A. M. Klein, A. Kruess, I. SteffanDewenter, and C. Thies. 2005. Landscape perspectives on agricultural intensification and biodiversity - ecosystem service management. Ecology Letters 8:857-874.

United Nations Conference on Environment and Development (UNCED). 1992. Agenda 21 - an action plan for the next century. Endorsed at the United Nations Conference on Environment and Development, New York, USA.

Van Huylenbroeck, G., and G. Durand, editors. 2004. Multifunctional agriculture: a new paradigm for European agriculture and rural development. Ashgate, Aldershot, UK.

Waldhardt, R. 2007. The Collaborative Research Center 299: An example of landscape ecological research? Colloquium Geographicum 28:27-47.

Waldhardt, R., D. Simmering, and A. Otte. 2004. Estimation and prediction of plant species richness in a mosaic landscape. Landscape Ecology 19:211-226.

World Commission on Environment and Development (WCED). 1987. Our common future. Oxford University Press, Oxford, UK.

Weinmann, B. 2002. Mathematische konzeption und implementierung eines modells zur simulation regionaler landnutzungsprogramme. Agrarwirtschaft Sonderheft 174.

Weinmann, B., J. O. Schroers, and P. Sheridan. 2006. Simulating the effects of decoupled transfer payments using the land use model ProLand. Agrarwirtschaft 55:248-256.

Wiggering, H., C. Dalchow, M. Glemnitz, K. Helming, K. Müller, A. Schulz, U. Stachow, and P.Zander. 2006. Indicators for multifunctional land use - linking socio-economic requirements with landscape potentials. Ecological Indicators 6:238-249.

Wilson, G. A. 2007. Multifunctional agriculture: $a$ transition theory perspective. CABI International, Cambridge, Massachusetts, USA.

Zander, P., A. Knierim, J. C. J. Groot, and W. A. H. Rossing. 2006. Multifunctionality of agriculture: tools and methods for impact assessment and valuation. Agriculture, Ecosystems and Environment 120:1-4. 